\title{
EDITORIAL
}

\section{Do velho ao novo: contextualização das infecções virais na infância}

\author{
Arnildo Linck Junior ${ }^{1}$, Flavia Lopes Gabani ${ }^{2}$
}

Autor correspondente: Flávia Lopes Gabani. Av Robert Koch, 1570, Rua 3, Casa 202, Londrina (PR) - Brasil. (43) 991224323. lopesgabani@gmail.com

Como citar esse artigo:

JUNIOR, A.L; GABANI, F. L. Do velho ao novo: contextualização das infecções virais na infância. Advances in Nursing and Health, v. 4, p. 16-20, Londrina, 2022.

A história dos vírus com a humanidade rende enredos que trazem invejas aos mais criativos dramaturgos. Há um pouco de tudo, de protagonistas taciturnos e cruéis aos personagens romantizados, que ora são acossados, ora travam batalhas épicas com diferentes vilões. Há guinadas, reviravoltas, reinícios quando tudo parecia perdido, novas armas, armas obsoletas. Das outroras pestes ou pragas, inauguramos o século XX com a emblemática gripe espanhola, doença respiratória que ceifou a vida de milhões de pessoas, superando o próprio senhor da primeira grande guerra mundial. Eram tempos difíceis e limitados, em que a cura viria somente para aqueles fortes 0 suficiente para transpassar o período autolimitado da doença. Não havia antivirais, antibacterianos. No máximo o reconhecimento, o isolamento, a queima de fômites e, para os crédulos, a esperança traduzida em orações.

A ciência evoluiu, e junto dela o conhecimento. Em 1928, Alexander Fleming, a partir de um experimento acidental, descobriu a chave da farmacopeia antimicrobiana atual, a penicilina. Dali em diante, o ser humano sentiu-se fortalecido, com o empoderamento às avessas que 0 iludiria rumo ao falso status de invencível, tornando-o arrogante, a ponto de afrouxar medidas restritivas e higiênicas; afinal agora havia a penicilina. Triste e perene engano, perpetuado na era contemporânea em que nos agarramos às panaceias utópicas e por vezes negligenciamos 0 essencial. Nas décadas seguintes a população mundial atingiu e multiplicou-se em 10 dígitos, mas jamais ficaria desacompanhada das 
,

estruturas

vivas mais simples,

microscópicas e letais, os vírus.

O Influenza, personagem principal da gripe espanhola, voltaria caprichosamente nas décadas seguinte, mudando apenas a alcunha do seu mal, por vezes relacionadas ao seu nicho. O vírus exerceu seu grande potencial de mutação e adaptação. E quando não havia humanos suficientes para testar seus mecanismos de aprimoramento, ou que resistissem à sua entidade nosológica, utilizou-se de outras espécies, verdadeiros laboratórios vivos e disponíveis para a sua replicação e disseminação, que deixou de permanecer circunscrito a um local para atingir proporções globais, com a recente pandemia de 2009. E quem julga que sua história já teve seu epílogo afoga-se em doces ilusões. E não estamos comentando apenas sobre o H1N1 (subtipo de Influenzavirus A e a causa mais comum da influenza (gripe) em humanos, com o H significando a proteína hemaglutinina e a letra $\mathrm{N}$ a proteína neuraminidase) ou sobre a estrela da vez, o H3N2 (segunda estirpe de vírus mais comum, depois do H1N1), mas em novas mutações com potenciais pandêmicos imprevisíveis.
Mas o Influenza nunca esteve sozinho. Num folhetim dissimulado e de fazer inveja às tramas épicas, outros personagens fazem-se notórios, como o metapneumovírus, com suas recorrentes pandemias regionais, do eterno rinovírus e suas corizas e tosses persistentes, do mórbido adenovírus, ousado em sua disseminação e capacidade de atingir diferentes órgãos e sistemas, ao superstar da virologia moderna, o coronavírus, que dispensa apresentações no contexto epidemiológico atual. Disso surgiu a necessidade do homem moderno, ou que se julga assim, de enfrentar esses imperceptíveis seres vivos, com os inibidores de enzimas virais, os agentes capazes de impedir a multiplicação, os moduladores da atividade inflamatória, os anticorpos monoclonais, as vacinas. A tecnologia serviu de insumos aos seres humanos, proporcionando fôlegos intermitentes, que garantissem a sobrevivência, sob o ponto de vista humano, ou um número expressivo de cobaias, nos processos relativos à multiplicação viral.

Da sombra de tantos anti-heróis, fezse notar gradativamente um agente especializado em crianças, o Vírus Sincicial 
Respiratório (VSR). Tantas vezes subestimado e rotulado como sazonal, de imediato o VSR mostrou que não escolhera bolsões no mundo subdesenvolvido. O seu alcance é global, do primeiro ao terceiro mundo. Responsável por um volume crescente da admissão de lactentes com insuficiência respiratória, o vírus destruiu paradigmas etários e climáticos. Além disso, cansou-se de ser conhecido como algoz de indivíduos portadores de condições crônicas complexas, expandindo seu potencial de morbimortalidade para crianças e adultos saudáveis, ou eutróficos, na preferência de alguns. Por meio de vieses conhecidos e desconhecidos, experimentamos atualmente surtos de bronquiolites em plenos dias quentes de verão, com vítimas de diferentes intensidades. Para a maioria, felizmente, o desfecho dar-se-á na segurança dos lares, sob as égides de seus protetores. Para outros, independente do desfecho, haverá um período de purgatório cumprido nas UTI, conectados aos respiradores, sendo mantidos sedados, por vezes bloqueados, enquanto aguardamos passivamente pelo autolimite da doença. Não devemos esquecer que nessa doença menos é mais, e na ausência de tratamentos específicos, resta-nos a tentativa de evitar prejuízos maiores.

O que trouxe esse enigmático vírus viver o seu amor em tempos de tantas outras cóleras pode ainda permanecer na penumbra de mistérios folclóricos ou ricos em dramaturgia, mas o fato não se despe da negligência que cometemos conosco e nossos dependentes, quando aglomeramos, quando falamos alto ou mais alto com quem muitas vezes nem nos ouve. Negligência testada e atestada, quando ignoramos recomendações de autoridades sanitárias, quando deixamos a máscara no queixo, no punho, no cotovelo ou mesmo sobre a mesa. Negligência maior quando ignoramos a secular recomendação de lavar as mãos. O Natal de 2021 trouxe, a despeito do espírito de São Nicolau, a sensação de que o mal estava sendo vencido e que chegara a hora dos espumantes. Fomos às compras, lotamos lojas e shoppings; falamos como se gritássemos, tocamos em corrimões, escadas rolantes, esquecemos dos limites de segurança que funcionam como espécies de escudo. Na expectativa de um Natal como nos velhos tempos, trouxemos velhos vícios e contaminamo-nos e, adoecendo ou não, levamos pestes, pragas, vírus a quem não 


\section{tin}

teve o direito da escolha, nossos filhos, sobrinhos, netos, nossos pequenos.

O desfecho segue aquém de nossa visão e capacidade de entendimento. Mas lições devem ser aprendidas, com ou sem o auxílio de nossa vontade. É imperativo acreditarmos em etiquetas higiênicas e medidas sanitárias. É salutar entendermos que nem tudo deve seguir o caminho do coletivo e que pequenos prazeres sempre estiveram em nossas casas, junto aos nossos. Não vamos ter perdão ou indulgência dos vírus. Ao contrário, nessa eterna guerra com seres em diferentes níveis de complexidade celular, tudo aponta para um único vencedor, aquele que sempre esteve aqui, antes mesmo de nós sermos o que somos. A indústria farmacêutica não vai romper o seu compromisso perene com o capitalismo e vai continuar investindo em medicações de uso crônico. Não há perspectivas para novos antivirais, não com eficiências devidamente comprovadas. Os leitos de UTI vivem o seu auge de ocupação. Os hospitais terciários e quaternários são as mesmas instituições de sempre. Nessa odisseia não sonhada nem por Ulisses, somos personagens coadjuvantes. E não adianta criar falsos profetas ou se intitular como um. Disseminar falsos conhecimentos em redes sociais, encaminhando Fake News, é portar-se como fanfarrão, em tempos em que a divina comédia ficou para preencher nossas bibliotecas.

Do ponto de vista de profissionais da saúde, o cuidar de criança envolve, antes de tudo, a responsabilidade. Essencial é orientar aos cuidadores que se mantenham e comportem-se bem. Do outro lado da maca estamos nós, enfermeiros, médicos, fisioterapeutas, servindo de esteio a quem precisa de nós. As informações estão disponíveis, e nunca foi tão fácil acessá-las. Cabe-nos o aproveitamento, sem maniqueísmos, deixando para outros tempos doutrinas cartesianas. Tempos difíceis requerem rompimento de pragmatismos rançosos e sem fundamentos. É dever de quem cuida reconhecer as adversidades, estabelecer metas e estratégias, independente do que eu, você ou nós acreditamos. É dever nosso, profissionais da saúde, aceitar as evidências e fazer honra aos que nos disponibilizaram opções fundamentadas em evidências. E jamais esquecer que somos privilegiados, entre tantos desfavorecidos, tendo a certeza de 
que tudo é para eles, por eles e com eles. É

o momento de deixarmos a zona de conforto

de personagens passivos e assumir a

postura dos que são os verdadeiros

narradores. 